\title{
UNIÃO HOMOAFETTVA: ASPECTOS CIVIS E CONSTITUCIONAIS
}

\author{
Irene Rodrigues \\ Mestre e Doutoranda em Direito (ivil pela \\ Faculdade de Direito da Universidade de São Paulo. \\ Cintia Regina Béo \\ Doutoranda em Direito do Estado pela Faculdade de \\ Direito da Universidade de São Paulo.
}

Resumo:

A natureza da união homoafetiva advinda de aspectos históricos, a questão da constitucionalidade da união em si e a atual situação juridica perante o Direito Civil brasileiro, além das estudadas conclusões para o tema que tem sido pauta do Direito legislado da maioria dos Estados democráticos.

Abstract:

The nature of the homoafective union came from historical aspects, the question of the constitutionality of the union in itself and the current legal situation towards the Brazilian Civil Law, beyond the studied conclusions for the subject that has been guideline of the legislated Right of the majority of the Democratic States.

Unitermos: união homoafetiva; Direito Comparado; Direito Legislado; situação jurídica atual.

Keywords: homoafective union; Comparative Law; Legislated Right; current legal situation.

Sumário: I Introdução. II - Aspectos Históricos. III - Natureza juridica da união homoafetiva. IV A questão da constitucionalidade da união de pessoas do mesmo sexo. $V$ - Breve exame de direito comparado no tocante à caracterização das uniões de homoafetivas. VI - Situação jurídica atual das uniões homoafetivas perante o Direito Civil brasileiro: direito legislado e jurisprudencia. VII. Conclusões. VIII-Bibliografia.

I. Introdução.

O presente estudo trata de um tema muito controvertido, as relações entre pessoas do mesmo sexo. as uniões chamadas homoaletivas e suas conseqüencias jurídicas. Ao se estudar tal questão é patente o tratamento preconceituoso. sobretudo 
por aqueles que não toleram simplesmente o fato da existência de tais uniões e, conseqüentemente, que sequer admitem a discussão de relações sociais, que se tornaram juridicas e relevante na sociedade hodierna.

Como estudiosos do Direito, apesar de todos termos conceitos próprios, orientações éticas, morais e religiosas, temos que fazer uma análise do fato incontestável que está em nossa realidade e, somente assim, podermos analisar os valores e alcançarmos a norma que possa ser fruto de um consenso e incorporar-se ao nosso sistema. Nossa tentativa é de analisar a questão de um ponto de vista eqüidistante para contribuir para o tema trazendo reflexões jurídicas, dada à sabida relevância social que as uniões homoafetivas vêm adquirindo, sendo, portanto, objeto digno e devido de estudo e tratamento legal, juriprudencial e doutrinário.

\section{Aspectos Históricos.}

Antes de examinarmos a questão da união homoafetiva como se caracteriza atualmente, cabe-nos uma análise breve sobre o que é o homossexualismo. seu histórico e a correta terminologia a ser empregada, a fim de que possamos melhor compreender este fenômeno e dar-lhe o tratamento jurídico adequado para o entendimento possível no início do século XXI.

O termo homossexualismo designa homo (igual) sexus (sexo), portanto, qualquer pessoa que sinta desejo sexual por pessoas do mesmo sexo, portanto entre homens ou entre mulheres. Entre as mulheres o homossexualismo também pode ser chamado de lesbianismo ou safismo. A origem destes termos está na prática da poetisa Sapho, que habitava a ilha grega de Lesbos, no mar Egeu que acabou por fundar uma sociedade de mulheres nesta ilha que entre outras coisas cultivavam sua atração por outras mulheres. Assim, lesbianismo vem do nome da ilha e safismo como a doutrina da poetisa (cujos trabalhos quase tudo se perdeu durante a Idade Média e têm-se apenas poucos registros).

O homossexualismo era uma prática muito comum na Grécia e na Roma. entre jovens do sexo masculino e homens adultos. Na Grécia era muito comum o relacionamento homossexual entre os jovens e entre estes e seus mentores. Em Roma, o homossexualismo também era uma prática comum. no entanto, um homem não poderia ser passivo sexualmente em relação a seus subalternos, havendo uma certa hierarquia de poder. 
Assim, ainda que na antigüidade clássica greco-romana já se delineava a família monogâmica e heterossexual como padrão jurídico, a prática homossexual era freqüente e não possuía estigmas negativos de oposição sistemática.

Já a cultura judaico-cristã, como a cultura muçulmana, condenava esta prática e a considerava pecaminosa. Com a decadência da cultura helênica e a queda do Império Romano com a conseqüente ascensão do cristianismo nos primeiros séculos de nossa era, o homossexualismo passou a ser, além de um pecado, banido, proibido, e, em alguns casos, considerado crime.

Nos países islâmicos o homossexualismo é considerado crime até hoje. Há que se ter em mente que na cultura islâmica o direito ainda é extremamente influenciado pela religião, diferentemente dos países ocidentais, razão pela qual, aquilo que é considerado uma perversão, uma violação perante os dogmas religiosos certamente se tornará um ilícito penal. Desta forma há punições com reclusão severa, de 8 (oito) anos, prisão perpétua e até mesmo a imposição da pena de morte, como no Irã.

Veja-se como o tema é controverso, que a Igreja Católica, em sua mais recente edição do "Lexicon", seu dicionário de termos, publicado em agosto de 2003 , considera que o homossexualismo é uma doença, devendo, portanto, entender-se tratarse de um mal passível de tratamento e cura.

Interessante, contudo, ́́ observar que em paises ocidentais, nos quais a religião não é mais o fundamento do direito posto, ainda se condenou ou se condenava até muito recentemente a prática homossexual. Na Inglaterra, por exemplo. o homossexualismo deixou de ser crime apenas nos anos 60. O mesmo ocorreu nos Estados Unidos, onde as manifestações públicas do homossexualismo em alguns Estados eram contravenção ou crimes de menor potencial ofensivo.

Vale dizer que na Inglaterra, atualmente, as demonstrações públicas de afeto entre homossexuais não são permitidas, de forma que a polícia age ostensivamente na repressão de qualquer manifestação nesse sentido. Aída Kemelmajer de Carlucci, profussora de Direito Civil da Universidade de Mendoza e ministra da Suprema Corte de Justiça de Mendoza, Argentina, afirma, de forma clara a respeito que: "Los homosexuales se quejan de que la policia inglesa, frecuentemente, se esconda en los baños públicos para "pescarlos" "I

I "Derecho y homosexualismo en el derecho comparado", Editora Juruá. 
Alúm de ser considerado um pecado, um atentado à religião, um ato moralmente reprovável. e um ilícito penal, o homossexualismo durante muito tempo esteve sob escrutínio das ciências médicas, sendo considerado um transtorno psiquiátrico e passível de tratamento.

Fntretanto, o homossexualismo deixou de figurar na Classificação Internacional de Doenças (CID número 302) em 1985, quando foi tornada sem efeito tal classificação. ${ }^{2}$ Este consenso foi alcançado em 1985, mas nos EUA, apesar da legislação em alguns Estados não haver avançado até hoje, já desde 1973. a Conselho de Psiquiatria daquele pais, pioneiramente, não considerava mais o homossexualismo como doença psíquica, passível de tratamento.

Assim também o termo homossexualismo deixa de ser o correto, posto que em Medicina o sufixo "-ismo" é designativo de doença, ao passo que o sufixo "dade" significa modo de ser e agir, sendo, portanto, o termo correto a designar a situação daquele que possui afetividade por pessoas do mesmo sexo homossexualidade. ${ }^{3}$

Desta forma, a homossexualidade deixou de ser considerada um transtorno psiquiátrico. As suas causas ainda são desconhecidas, mas as pesquisas mais recentes não descartam fatores hereditários, genéticos, visto que estariam combinados com fatores ambientais, com fatores sociais e que um homossexual, em maior ou menor grau. mantém características de heterossexual.

Diante disso, sejam as causas multifatoriais, de origem genética, social, ou-não, o fato é que o homossexual, seja ele feminino ou masculino, merece respeito como ser humano, e suas relações afetivas e patrimoniais, gerando efeitos jurídicos. necessitam. como demonstraremos. de urgente estudo, regulamentação e reconhecimento em nosso ordenamento.

A dignidade da pessoa humana, como valor fundante de nosso ordenamento jurídico (art. $1^{\circ}$, inciso III, da Constituição Federal), posto que inegável que a sexualidade é um aspecto decorrente da natureza humana, e o princípio da

2. Hả que se ressaltar que recentemente no Brasil, o Conselho Federal de Psicologia baixou resolução proibindo que psicólogos nacionais se manifestassem em órgãos de comunicação de massa ou qualquer manifestação pública que implicasse em atribuir aos homossexuais a condição de portadores de qualquer desordem psíquica. Trata-se da Resolução n. 1, de 22 de março de 1999, do Conselho Federal de Psicologia.

3. A respeito: TAlaVERA, Glauber Moreno - Avanços e Retrocessos do Novo Código Civil. São Paulo: Editora Saraiva, 2002, p. 183. 
igualdade, que em si contém, seguramente, a orientação sexual individual (art. $5^{\circ}$. caput da Constituição Federal), nos impõem um estudo que respeite os valores éticos da sociedade brasileira, mas que merecem um sopesamento diante dos valores constitucionalmente estatuídos com vistas à finalidade se formar uma sociedade mais justa, livre e sulidária, como a própria Carta da República propõe (art. $3^{\circ}$ inciso I).

III. Natureza jurídica da união homoafetiva.

No atual estado em que se encontra a legislação civil e nossa Constituição Federal, não há que se cogitar que a convivência de duas pessoas do mesmo sexo possa constituir um casamento. $\mathrm{O}$ art. 226 da Constituição Federal trata da familia ¿ de sua proteção pelo estado, e em seu $\S 5^{\circ}$ expressamente estatui que os direitos e deveres conjugais deverão ser exercidos igualmente pelo homem e pela mulher.

Daí já se pode entender que desde nossa Constituição Federal, o termo casamento somente pode ser entendido em sentido estrito como a união heterossexual. E, aplicando-se as regras de hermenêutica constitucional, de que a Constituição Federal não é um documento para o jurista e sim para o cidadão, e que aos termos por ela empregados deve se dar a interpretação comum e corrente, não poderiamos, então, entender que casamento $\dot{i}$ a união de pessoas de mesmo scxo, posto que o costume e a tradição é que o casamento como base familiar é uma união heterossexual.

Somente poderíamos, ao interpretar a Constituição Federal, entender que a expressão "casamento" nela contida indica as uniões heterossexuais e homossexuais se nos valêssemos de uma interpretação evolutiva. Nas palavras de Uadi Lamego Bulos, teríamos que o método evolutivo "visa adaptar os preceitos constitucionais aus fatos novos, conferindo ao intérprete uma abertura maior para a compreensão dos termos prescritos na norma constitucional, os quais comportam, não dificilmente. conteúdos elásticos, vagos, ambíguos, de determinação plurivoca (...)" 4

Assim, mesmo diante da interpretação evolutiva, não conseguimos vislumbrar tal elasticidade na definição do termo casamento, ou de alteracões sociais

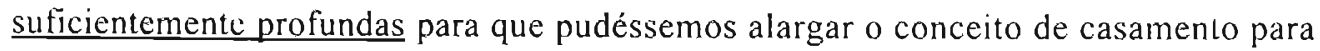
uma união milenarmente heterossexual.

4. BULOS, Uadi Làmego. Manual de Interpretação Constitucional. São Paulo: Saraiva, 1997, p. 52. 
Casamento, portanto, não pode ser a definição de perfil constitucional da união homoafetiva. Do mesmo modo, a convivência de pessoas do mesmo sexo nãogera união estável. Isto porque a convivência duradoura da união estável é o chamado concubinato puro e deve ser possível sua conversão em casamento, sendo a Constituição Federal clara na diversidade sexual para sua caracterização.

\section{$\S 3^{\circ}$ Para efcito da proteção do Estado, é reconhecida} a união estável entre o homem e a mulher como entidade familiar, devendo a lei facilitar sua conversão em casamento.

Necessário se faz registrar, posições contrárias como da Desembargadora (jaúcha, Maria Burenice Dias, que atĩrma que a discriminação que ocorre neste capítulo da família violaria o art. $5^{\circ}$ Estaríamos diante de uma injustificável discriminação do $\$ 3^{\circ}$ do art. 226 da Constituição Federal, das leis da união estável (8.971/94 e 9.278/96) que somente contemplam as uniões homem-mulher, que a dignidade da pessoa humana transcende este aspecto. E inclusive cita as decisões do Tribunal de Justiça do Rio Grande do Sul, que reconhecem dircitos patrimoniais, sucessórios como se uniões estáveis fossem. ${ }^{5}$

Haveria, ademais, uma interpretação mais ampliativa, no posicionamento de Paulo Luiz Neto Lobo ${ }^{6}$ posto que no caput do art. 226 haveria se operado a mais radical transformação, no tocante ao âmbito de vigência da tutela constitucional à família.

Isto porque não haveria qualquer referência a um determinado tipo de família, como ocorreu com as constituições brasileiras anteriores. Segundo este entendimento, ao suprimir a locução "constituída pelo casamento" (art. 175 da Constituição, de 1967, com a redação dada pela Emenda Constitucional n. 1/1969),

5. DIAS, Maria Berenice. União Homossexual. Aspectos sociais e juridicos. Disponivel em Cuadernos de Bioetica[versão digital]. seção Doutrina ISSN 0328-8390. http://www.cuadernos.bioetica.org/doctrina 17.htm. DIAS, Maria Berenice - União Homossexual: o preconceito e a justica, Porto Alegre: Livraria do Advogado, 2000.

6. LOBO. Paulo Luiz Neto - Entidades Familiares ('onstitucionalizadas: Para além do mmenus clausus. in Nova Realidade do Direito de Familia. Tomo 1. Rio de Janeiro: COAD SC Editora Juridica, 1998 , p. $50-57$. 
sem substituí-la por qualquer outra, pôs sob a tutela constitucional "a família", ou seja, qualquer família. A cláusula de exclusão haveria desaparecido.

O fato de, em seus parágrafos, o art. 226 se referir a tipos determinados, para atribuir-lhes certas conseqüências jurídicas, não significaria a manutenção da cláusula de exclusão, como se ali estivesse a locução "a família. constituída pelo casamento, pela união estável ou pela comunidade formada por qualyuer dos pais e seus filhos"

A interpretação dada pelo constitucionalista, portanto, seria de que uma norma ampla não pode suprimir de seus efeitos situações e tipos comuns, restringindo direitos subjetivos.

Decisões como estas da Desembargadora Maria Berenice Dias, ou interpretações como a referida supra de Paulo Luiz Neto Lobo, pioneiras, se encontram, contudo, isoladas na doutrina e na jurisprudência pátrias que. majoritariamente, entendem que a união estável, como entidade familiar, da forma como está prevista na Constituição Federal não pode ser aplicada às relações homoafetivas.

Diante disso, se recorrêssemos a um tertium genus, a união homoafetiva seria constitucional? Esta é indagação que se impõe e que trataremos de analisar, ainda sob a perspectiva constitucional.

Parece-nos que o reconhecimento da união homoafetiva para fins patrimoniais, de meação, de beneficios previdenciários e até mesmo sucessórios é constitucional, não havendo qualquer discrepância com os princípios de nossa Carta Magna. Contrariamente, o reconhecimento destes direitos viria a preservar direitos fundamentais de pessoas com orientação homossexual e que merecem tutela de seus direitos fundamentais tanto quanto os heterossexuais, não se podendo, de forma alguma, diferenciá-los para fruição destes direitos.

Contudo, csta união não poderia surtir os mesmos efeitos que um casamento ou uma união estável. Para que esta união homoafitiva seja reclassificada como casamento ou união estável, ou seja, entidade familiar, necessária scria uma emenda constitucional. Para o reconhecimento dos direitos patrimoniais, previdenciários, dentre tantos outros, desde que não caracterizando uma entidade familiar, não haveria óbices, em nossa opinião, de ordem constitucional. Apenas o reconhecimento como entidade familiar seria excluído, no mais, todos os outros direitos que a legislação e a jurisprudência atribuirem aos homossexuais que possuam uma relação duradoura, serão constitucionais. 
Ressalte-se que a maior controvérsia se encontra no fato da união homoafetiva se constituir em uma unidade familiar posto que além dos direitos patrimoniais estaremos diante da expressa possibilidade de adoção, da tutela do bem de família, enfim, de inúmeros direitos correlatos ao casamento que conseqüentemente seriam atribuídos à união homoafetiva, são o pomo da discórdia entre os operadores do Direito.

Contudo, concluímos que apesar de no corrente interpretar de nossa Constituição Federal, não podermos tratar de um casamento entre pessoas do mesmo sexo, ou de uma união estável, devemos ressaltar que é imperioso o reconhecimento de efeitos à realidade social da união homoafetiva, posto que esta interpretação se coaduna com os direitos fundamentais garantidos.

V Breve exame de direito comparado no tocante à caracterização das uniões de homoafetivas.

A análise da legislação alienígena, considerando a evolução cronológica, se cingirá aos seguintes aspectos: natureza jurídica da união homoafetiva, os efeitos patrimoniais atribuidos a esta união, os direitos sucessórios desta decorrentes e, por fim, direitos previdenciários aplicáveis.

Em 1987, o Parlamento sueco posicionou-se a favor da concessão de determinados benefícios à parte menos favorecida da relação homossexual, com o tímido Homosexual Cohabitants $\mathrm{Act}$, pouco mencionado pelos doutrinadores em razão da quase inexpressiva contribuição para com o reconhecimento jurídico em si da união homoafetiva, mas que não pode ser negado como o primeiro ato legislativo tendente ao reconhecimento jurídico deste fato, posto que garantia o direito de residência (posto que havia coabitação).

A Dinamarca é considerada a primeira nação a admitir a necessidade da tutela estatal para concessão de direitos advindos de uniões homossexuais nas áreas previdenciária, trabalhista e do direito das sucessões. incluindo também a troca de sobrenomes e dando as diretrizes em caso de dissolução da sociedade, através da combinação de várias leis.

Isto ocorreu em 1989, com a permissão do rcgistro da parceria, e a pussibilidade de sua dissolução feita em vida como uma separação judicial, com 
partilha de bens inclusive. Outrossim, deferiu a legislação o direito à herança e proíbe como crime contrair duas parcerias (como dois casamentos dariam origem à bigamia).

A Noruega, em 1993, acompanha a Dinamarca, garantindo às uniões homoafetivas todos os direitos supracitados (patrimoniais, direito à herança, entre outros) acrescentando o poder parental negado pela lei dinamarquesa, abrindo-se, portantu a possibilidade da adoção por homossexuais que possuíssem uma união. Este é outro tema extremamente controvertido e negado muitas vezes em legislações avançadas, no qual o presente estudo não pretende avançar, posto que seria objeto de análise própria, devido à sua complexidade intrinseca.

Em 1995, a Suécia reformulou sua posição jurídica frente à questão. estabelecida e, 1987, passando a conceder aos homossexuais os mesmos direitos já constantes da lei dinamarquesa, em vigor desde 1989, através da chamada "partenariat" portanto, direitos trabalhistas, sucessões. previdenciários, troca de sobrenomes e até caso de dissolução inter vivos.

Ambas as nações (Suécia e Dinamarca) tiveram a preocupação em promover diversos debates entre juristas. legisladores e autoridades eclesiásticas, incluindo levantamentos e pesquisas acerca do modus vivendi dos casais homossexuais, concomitante com as pesquisas de opinião junto à população, numa tentativa de conciliar, com bom senso e lógica, argumentações políticas, técnicas e religiosas, radicalmente opostas.

O Parlamento holandês, no ano de 2000, promoveu a aprovação da lei que equiparou as uniões homossexuais ao casamento tradicional, por 107 votos contra 33, num intenso debate com a duração de três dias. Salienta-se que independente das discussões de cunho político travadas, as pesquisas realizadas entre os cidadãos holandeses demonstraram que $85 \%$ deles eram a favor da aprovação do casamento entre pessoas do mesmo sexo.

Por fim, em 01/04/01 foram celebrados em Amsterdã os primeiros casamentos homossexuais, sob a égide da nova lei. Ressalte-se que esta lei é completa, permitindo, inclusive, a controvertida adoção por casais homossexuais.

Na América do Sul temos alguns avanços na matéria na Argentina. No dia 20 de maio de 2003 foi regulamentada Lei da Provincia Autônoma de Buenos Aires (editada em 12/12/2002) que prevê o registro das uniões civil entre pessoas do mesmo sexo. São necessárias no mínimo duas e no máximo cinco testemunhas para que seja feito o registro desta união. 
A lei portenha serve tanto às uniões que classificamos como estáveis (uniões de fato no direito local) ou para a união homoafetiva. É necessário provar uma convivência estável e duradoura de no mínimo dois anos ou descendentes comuns (ou seja filhos, da união estável). Há. inclusive, impedimentos, a saber: parentesco em linha reta, colateral (irmãos), mesmo que por esse parentesco seja por adoção, que esteja casado ou que tenha outra união (de fato).

Apesar de muito alarde pela Imprensa à época da aprovação da legislação acreditamos pela forte influência da Igreja Católica no país - há que se ressaltar que se trata de uma lei de validade estadual (editada pela Província de Buenos Aires) e que os direitos concedidos na lei estadual são somente e estritamente patrimoniais: a partilha dos bens decorrentes da união. Sequer o direito à sucessão é concedido.

A dissolução pode ser feita por mútuo acordo, por vontade de uma das partes (o que assume o caráter litigioso), por matrimônio posterior (dos casais heterossexuais) e pela morte de um dos integrantes da união civil. A dissolução é feita no cartório mediante denúncia ou distrato, dando-se, portanto, a essa união um caráter eminentemente contratual, longe dos laços afetivos e institucionais de um casamento ou mesmo da união estável como reconhecida pelo Direito brasileiro.

Por fim, gostaríamos de esclarecer a questão nos Estados Unidos da América, uma vez que o sistema federalista existente neste país torna mais complexa ainda a questão.

Em meio a grande polêmica, em 1993, a Suprema Corte do Havaí, declarou que o Governo deveria provar a necessidade da proibição da entrega de certidões de casamento a casais do mesmo sexo, sob pena de serem violadas as proteções contra a discriminação contidas em sua Constituição Federal.

O precedente havaiano lez com que vários outros Estados adotassem posturas semelhantes (Oregon, Colorado, Califórnia e Vermont) e outros se posicionassem no outro extremo (Maine, Geórgia Michigan, Oklahoma), levando o Congresso norte-americano a aprovar o chamado Defense Of Marriage Act, segundo o qual uma unidade da Federação não é obrigada a reconhecer o registro de casamentos homossexuais concedidos por outra unidade da Federação. Ora. tal lei foi contestada por vício de constitucionalidade. posto cue expressamente, pela Constituição Federal dos Fstados Unidos, um Estado não pode negar fé pública a documento emitido por outro Estado. 
Assim, a questão se torna complexa e de difícil resolução pelas peculiaridades federais e constitucionais americanas. Isto porque qualquer Estado tem autonomia para tutelar a união homossexual ou para repeli-la (ainda que isto, dependendo do caráter da legislação local poderia caracterizar discriminação ou qualquer tipo de violação da Constituição Federal). Mas, ao mesmo tempo em que se possui esta autonomia, não se pode negar a documentação de outro Estado federado que reconhece a união homoafetiva.

Desta forma, um Estado que não-adota a união homoafetiva considera sua autonomia violada, quando é obrigado a reconhecer a união contraída em outro Estado da Federação. Acreditamos que somente diante de um consenso nacional a questão poderá ser resolvida a contento. $\mathrm{Na}$ ausência deste consenso, sem dúvida alguma, será a Suprema Corte Americana levada a decidir a questão, mormente, pela constitucionalidade ou-não da união homoafetiva, de modo uniforme, para todo o país.

Atualmente reconhece-se a parceria, mas não-casamento entre pessoas do mesmo sexo em catorze Estados da federação americana. Somente o Estado de Vermont. em 2000, equiparou a união homossexual ao casamento. Por fím, entretanto, há que se ressaltar que apesar dos tribunais estaduais estarem concedendo vários direitos a pessoas do mesmo sexo que se encontram em união, o Executivo Federal vem estudando medidas em sentido contrário e se pronunciando sistemática e peremptoriamente contra as uniões de pessoas do mesmo sexo, demonstrando que naquele país a questão se encontra longe de ser consensual.

VI. Situação jurídica atual das uniões homoafetivas perante o direito civil brasileiro: direito legislado e jurisprudência.

A união homoafetiva não possui um tratamento sistemático no ordenamento brasileiro. Seu estatuto se define por leis esparsas e por decisões judiciais majoritárias, o que, obviamente, traz insegurança juridica aos homossexuais em relação aos seus direitos e deveres no Direito pátrio. Vejamos os principais aspectos da questão.

Na vigência do Código Civil, de 1916, como não havia previsão expressa de que a diferença de sexos era o pressuposto - tão arraigado o conceito era que se considerava desnecessário citá-lo - que não constava sequer como impedimento. Mas isto nunca foi motivo para que se aceitasse o casamento entre pessoas do mesmo sexo. 
Foi considerado que a diversidade sexual, tal qual a celebração e o consentimento eram pressupostos do casamento.

Assim, aplicava-se a teoria que os atos jurídicos podem ser inexistentes, nulos ou anuláveis. No caso do casamento de pessoas do mesmo sexo o ato era tido como inexistente e, portanto, apesar do reconhecimento judicial, nenhum efeito produzia. O pressuposto da diversidade era entendido como interpretação da existência de deveres do marido e da mulher, da prole, da questão até do defloramento anterior. Era uma interpretação sistemática.

Nos poucos casos de que se tem notícia em que chegou a ser celebrado um casamento entre pessoas de mesmo sexo, cita Álvaro Villaça de Azevedo que os mesmos foram declarados inexistentes, um caso em Minas, de duas mulheres e outro em São Paulo, julgado pelo Tribunal de Justiça, em 1986, um pouco mais complexo, posto que ambos eram homens, mas um deles utilizou um registro falso de nascimento (RT 615/47).

De certa forma o Código Civil vigente acaba com qualquer dúvida com relação à necessidade de diversidade de sexos para o casamento, de acordo com o art. 1.514:

Art. 1.514. O casamento se realiza no momento em que o homem e a mulher manifestam, perante o juiz, a sua vontade de estabelecer vinculo conjugal, e o juiz os declara casados.

I:stabelecido, destarte, que o casamento não pode ser contraído por pessoas do mesmo sexo, o Código Civil, de 2002, também o exclui do âmbito da união estável, impondo-se a diversidade de sexos como pressuposto para sua concretização:

Art. 1.723. É reconhecida como entidade familiar a união estável entre o homem e a mulher, configurada na convivência pública. continua e duradoura e estabelecida com o objetivo de constituição de família. 
Saliente-se, entretanto, que o Tribunal de Justiça do Estado do Rio Grande do Sul. pelos motivos já expostos no exame da constitucionalidade da união homoafetiva. equipara esta à união estável, garantindo-lhe os mesmos direitos. Não se pode olvidar, entretanto, que somente este Tribunal da federação adota tal entendimento, não-acolhido pelos demais tribunais estaduais e nem pelo Superior Tribunal de Justiça ou pelo Supremo Tribunal Federal.

Entretanto, alguns avanços no Estado do Rio Grande do Sul devem ser dignos de nota. Pioneiro é o posicionamento do Tribunal de Justiça do Estado do Rio Grande do Sul, no tocante à documentação e comprovação da união homoafetiva. De forma inédita, o corregedor geral do referido tribunal, aos 17 de fevereiro de 2004 baixou provimento que acrescenta um parágrafo único ao art. 215 da Consolidação Normativa Notarial Registral, com o seguinte teor:

Parágrafo único - As pessoas plenumente capazes, independente da identidade ou oposição de sexo, que vivam uma relação de fato durudoura, em comunhão afetiva, com ou sem compromisso patrimonial, poderão registrar documentos que digam respeito a tal relação. As pessoas que pretendam constituir uma união afetiva na forma anteriormente referida também poderão registrar os documentos que a isso digam respeito.

Com a publicação deste ato, aos 3 de março de 2004, no Diário Oficial, os cartórios do Estado do Rio Grande do Sul passaram a entender possível a formalização da união entre pessoas do mesmo sexo, tendo sido registradas, logo após a entrada em vigor do provimento, de plano, oito uniões e muitos outros pedidos se encontram sob análise no atual momento.

Entretanto, apesar destas decisões e atos, devemos analisar o que ocorre nas uniões homoafetivas em geral, posto que não podemos nos olvidar o posicionamento sul riograndense é excepcional em relação aos demais Estados da Federação e diverso do entendimento dos tribunais superiores federais.

Apesar de não ser reconhecida a união homoafetiva como casamento ou união estável, os direitos patrimoniais começam a ser reconhecidos pelos tribunais 
pátrios. A jurisprudência tem reconhecido a união homoafetiva como uma união de fato, como se sócios fossem os parceiros, mas não como entidade familiar, nos termos do conceito que the empresta a Constituição e a legislação vigente, como já demonstramos.

Assim, no Rio de Janciro, decidiu-se que, à semelhança de um contrato de sociedade, o esforço ¿ a contribuição do parceiro devem ser levados em conta, na partilha dos bens, proporcionalmente à contribuição para a aquisição ou criação desses bens. em um caso em que duas pessoas possuíam uma união homoafetiva, vindo uma delas a falecer. Veja-se que não foi reconhecido um direito hereditário, mas, sim. aos bens adquiridos com o esforço comum, tal como a jurisprudência do Supremo Tribunal Federal estabeleceu, pioneiramente, os direitos decorrentes da união estável de pessoas do mesmo sexo. na Súmula n. 380 (de 1964), muito anterior ao reconhecimento constitucional e legal desta.

Diametralmente oposta foi decisão proferida pelo Judiciário mineiro, ponderando que a união de pessoas do mesmo sexo não geraria direito algum, independentemente do período de coabitação, negou qualquer direito em situação análoga à supracitada. Entretanto, o Superior Tribunal de Justiça reformou a decisão e admitiu o direito à partilha de bens adquiridos por parceiros em vista de sua mútua colaboração.

Significativo, portanto, tem sido o posicionamento do Superior Tribunal de Justiça que tem deferido o direito à partilha de bens entre pessoas do mesmo sexo, cujas uniões se dissolvem inter vivos ou mortis causa. Como o E. Superior Tribunal de Justiça tem a função de uniformizar a interpretação jurisprudencial, os precedentes desta Corte possibilitam que se vislumbre futuramente a pacificação do entendimento que é direito de companheiro de união homoafetiva, a partilha dos bens adquiridos com esforço comum.

Diferentemente o tratamento dado à questão no tocante à sucessão, uma vez que mesmo perante o Superior Tribunal de Justiça, não vem sendo reconhecido um direito à herança em uniões homoafetivas dissolvidas pela morte de um dos conviventes.

Quanto aos benefícios previdenciários, a situação é diversa. Afirmando que a Constituição Federal não faz qualquer distinção em relação à orientação sexual para o deferimento de benefícios previdenciários após a morte de um cônjuge. o ministro Marco Aurélio de Mello determinuu que, comprovada a "união estável" entre 
pessoas do mesmo sexo, o companheiro sobrevivente teria direito ao beneficio previdenciário de seu convivente falecido.

Este leading case, consistente na Petição n. 1984-9, contra a decisão proferida em Ação Civil Pública ajuizada perante a $3^{\mathrm{a}}$ Vara Previdenciária do Rio Grande do Sul, visava a cassação da liminar concedida para o deferimento dos benefícios para companheiros do mesmo sexo. Como o ministro Marco Aurélio, então presidente do Pretório Excelso indeferiu a suspensão, muitos homossexuais passaram a buscar junto ao Instituto Nacional de Seguridade Social o mesmo benefício, posto que se tratava de uma ação coletiva que obteve decisão favorável em sua origem e perante o Supremo Tribunal Federal e, portanto, produziria efeitos em todo o território nacional. Veja-se a decisão, in verbis:

"Constitui objetivo fundamental da República Federativa do Brasil promover o bem de todos, sem preconceitos de origem, raça, sexo, cor, idade e quaisquer outras formas de discriminação (inciso $I V$ do art. $3^{\circ}$ da Carta Federal). Vale dizer, impossivel é interpretar o arcabouço normativo de maneira a chegar-se a enfoque que contrarie esse principio basilar, agasalhando-se preconceito constitucionalmente vedado. O tema foi bem explorado na sentença (folha 351 à 423), ressaltando o Juizo a inviabilidade de adotar-se interpretação isolada em relação ao art. 226, $\$ 3^{\circ}$, também do Diploma Maior, no que revela o reconhecimento da união estável entre o homem $e$ a mulher como entidade familiar. Considerou-se, mais, a impossibilidade de, à luz do art. $5^{\circ}$ da Lei Máxima. distinguir-se ante a opção sexual. Levou-se em conta o fato de o sistema da Previdência Social ser contributivo, prevendo a Constituição o direito à pensão por morte do segurado, homem ou mulher, não-só ao cônjuge, como lambém ao companheiro, sem distinção quanto ao sexo, e dependentes inciso $V$ do art. 201 (...) Assim, não parece extravagante a óptica da inaplicabilidade da restrição criada inicialmente pela Medida Provisória n. $1.570 / 97$ e, 
posteriormente, pela Lei $n .9 .497 / 97$ à efícácia erga omnes, mormente tendo em conta a possibilidade de enquadrar-se a espécie no Código de Defesa do Consumidor. Indefiro a suspensão pretendida"

A princípio houve certa dificuldade na obtenção destes benefícios, posto que o Instituto Nacional de Seguridade Social se negava a reconhecer os direitos dos homossexuais. Chegou-se a reconhecer, por exemplo, que a Lei Municipal n. 16.730/2001 da cidade de Recife. que reconhece o direito de receber pensão ao sobrevivente de uma união homossexual, como a primeira do país.

Entretanto, após a referida decisão do Supremo Tribunal Federal, proferida aos 10 de fevereiro de 2003, e apesar de não haver decisão definitiva de mérito no processo referido, o Instituto Nacional de Seguridade Social emitiu. para cumprir a decisão liminar, a Instrução Normativa 50, de 8 de maio de 2001. estabelecendo os requisitos para a concessão de benefícios entre companheiros.

Ressalte-se. contudo, que apesar da decisão do Supremo Tribunal Federal e da sentença favorável da $3^{\mathrm{a}}$ Vara Previdenciária do Rio Grande do Sul, ainda há recursos pendentes de análise, interpostos pelo Institutu Nacional de Seguridade Social. Assim, ainda há possibilidade, mesmo que de menor grau devido à mobilização e à aprovação sociais, de reversão da decisão e não-consolidação, portanto, da situação ora vigente.

Conclui-se. portanto, que é necessária uma legislação ordenada e uniforme, que conceda às uniões homossexuais o devido reconhecimento que a jurisprudência já vem the dando. de forma a impedir litígios e trazer segurança jurídica a todos os envolvidos.

Neste sentido, tramita no Congresso Nacional o Projeto de Lei n. I.15I/95 de autoria da então deputada Marta Suplicy, substituído pelo Projeto de Lei n. 1.151-A/97 de autoria do deputado Roberto Jefferson.

$O$ projeto original estatui claramente que sua finalidade é garantir direitos fundamentais dos homossexuais e direitos patrimoniais. não sendo, portanto. uma tentativa de se equiparar a união homoafetiva ao casamento.

De acordo com o projeto de lei originalmente proposto. a união civil entre pessoas do mesmo sexo, designação dada às relações homoafetivas, seria 
registrada nos Cartórios de Pessoas Naturais e teria como requisitos a capacidade civil e a capacidade de contrair matrimônio, ou seja, somente pessoas aptas a contraírem o matrimônio (solteiras, divorciadas ou viúvas) poderiam contrair a união civil, medianti a apresentação de um instrumento público de contrato de união civil.

A dissolução da união civil poderia ser mortis causa ou por processo judicial, litigioso ou consensual. Com a dissolução da união seria feita a partilha dos bens das partes, de acordo com o que contrataram.

No mais, o bem imóvel de propriedade dos contratantes desta união seria protegido pela legislação correlata ao bem de família, e os direitos previdenciários, seja na esfera pública ou do setor privado garantidos por alterações nas leis federais $n$. 8.112/1991 e n. 8.113/1991, equiparando-se, para fins previdenciários, os contratantes de união civil aos conviventes em união estável

Por fim, os direitos sucessórios previstos na Lei n. 8.971/1994 (anterior ao Código Civil de 2002) seriam estendidos aos homossexuais contraentes. de forma inédita, a lhes garantir, basicamente, o direito ao usufruto vidual em concorrência com ascendentes e descendentes e, em caso de inexistência de outros herdeiros, a totalidade da herança. Outrossim, por força da extensão dos direitos contidos na referida lei, seriam devidos alimentos entre os contratantes.

O substitutivo apresentado pelo deputado Roberto Jefferson pouco modifica o projeto, apenas acrescentando-Ihe, em termos de direitos, o reconhecimento da parceria civil (designação adotada pela nova redação) para fins de preferência para concessão de vistos de permanência no país para estrangeiros que convivam com brasileiros no regime da parceria registrada; a atribuição da condição de dependente para fins da legislação tributária: reconhecimento para planos de saúde e para seguros de grupo e de composição de renda para a aquisição de casa própria.

Percebe-se que o substitutivo tratou de detalhes importantes do âmbito patrimonial e que repercutem na vida daqueles que possuem um relacionamento homoafetivo. Contudo, há que se salientar que algumas alterações no projeto devem ser feitas, para adaptá-lo ao Novo Código Civil.

Apesar de não se incluírem questões como a adoção ou mesmo a discussão da equiparação ao casamento, percebe-se que a segurança jurídica patrimonial e de outros direitos básicos estaria assegurada pela legislação proposta. 
VII. Conclusões.

No Direito brasileiro a convivência entre pessoas do mesmo sexo não tem nenhuma regulamentação satisfatória e sistemática. Vimos que os direitos que são reconhecidos aos homossexuais em união são decorrentes basicamente de julgados e de legislação local e esparsa.

Ao mesmo tempo é inegável a existência e o fato social relevante das uniões homoafetivas. E ainda que estas não possam ser caracterizadas como casamento ou como união estável, nos termos constitucionais, é imperioso que haja uma tutela jurídica destas situações, a fim de se trazer segurança jurídica aos envolvidos.

Apesar de todos os aspectos morais e religiosos envolvidos, faz-se necessário que a legislação - sobretudo em um país de tradição romanística como o nosso - venha a reconhecer ao menos os direitos patrimoniais daqueles envolvidos em uma união homoafetiva, por uma questão de justiça, posto que contribuíram para a formação daquele patrimônio.

Outrossim, o direito a benefícios previdenciários e outros direitos decorrentes de uma convivência em comum, que são reconhecidos a quaisquer pessoas que coabitem, com laços afetivos ou juridicos que as unam ou-não, também sejam reconhecidos aos homossexuais.

$\dot{E}$ imperioso que este reconhecimento seja feito, posto que a homossexualidade não pode ser confundida com clandestinidade. $O$ homossexual não pode sofrer qualquer discriminação em relação à sua orientação sexual, posto que o Direito pátrio, em status constitucional tem como princípios a não-discriminação e a dignidade da pessoa humana.

Assim, deve o homossexual ser respeitado, por sua dignidade como pessoa humana, sem nenhuma discriminação em razão de sua orientação sexual, que, ademais, não pode ser constitucionalmente fator de discrímen válido e aceitável em qualquer instância jurídica, seja para a admissão em um concurso público, ou para qualquer outro ato da vida civil.

A equiparação da união homoafetiva ao casamento ou à união estável não nos parecem ser possívcis no atual momento. Isto porque, como já ressaltamos, tal reconhecimento implica em necessidade de consenso social, de valores morais, sociais e religiosos. 
Contudo, o homossexual não pode ser colocado à margem da sociedade $\mathrm{e}$ discriminado. A tutela de sua dignidade como pessoa humana impede de plano que sequer se cogite de tal tratamento. Assim, entendemos que apesar da equiparação da união homoafetiva ao casamento ser uma questão que ainda precisa ser amplamente debatida na sociedade brasileira, como ocorreu em outros países, o homossexual e suas relações não podem sofrer da insegurança jurídica que ainda existe.

Desta forma, mister se faz a aprovação de legislação, o mais breve possivel, seja ela a proposta que já se encontra em trâmite ou outra desde que seja melhor coadunada com os interesses sociais e com os direitos dos homossexuais, posto que o projeto apresentado é satisfatório, para que haja segurança jurídica e ao menos se busque lograr erradicação ou sensível discriminação das pessoas do mesmo sexo que se unem e, assim, se respeite um princípio constitucional, direito fundamental, tão citado e tão olvidado: dignidade da pessoa humana.

São Paulo, abril de 2004.

VIII. Bibliografia.

AZEVEDO, Álvaro Villaça de. Estatuto da família de fato. São Paulo: Editora Jurídica Brasileira, 2001.

AZEVEDO, Álvaro Villaça de. União entre pessoas do mesmo sexo. Revista da Faculdade de Direito da Universidade de São Paulo, v. 94, p. 13-31. 1999.

MELLO, Celso Antônio Bandeira de. Conteúdo jurídico do principio da igualdade, São Paulo: Malheiros, 1996.

BARROS, Luiz Carlos de Barros. Adoção por homossexuais, Curitiba: Juruá, 2002.

BRITO, Fernanda de Almeida. União afetiva entre homossexuais e seus aspectos jurídicos. São Paulo: Editora LTR, 2000.

DIAS, Maria Berenice. Uniăo Homossexual: o preconceito e a justiça. Porto Alegre: Livraria do Advogado, 2000.

LOBO, Paulo Luiz Neto. Entidades Familiares Constitucionalizadas: Para além do numerus clausus. In: Nova Realidade do Direito de Familia, Tomo 1. Rio de Janeiro: COAD SC Editora Jurídica, 1998. p. 50-57.

TALAVERA, Glauber Moreno. Avanços e Retrocessos do Novo Código Civil. São Paulo: Editora Saraiva, 2002. 
TEXTOS DOS PROJETOS:

Projeto de Lei 1.151/95 de autoria da deputada Marta Suplicy

Projeto de Lei 1.151-A/97 de autoria do deputado Roberto Jefferson 